\title{
IDENTIFICATION OF RASTROCOCCUS RUBELLUS WILLIAMS (HEMIPTE RA: PSEUDOCOCCIDAE) ON MANGO: A NEW RECORD TO SRI LANKA
}

\author{
LD Galanihe ${ }^{1 *}$, GW Watson ${ }^{2}$ \\ ${ }^{1}$ Horticultural Crops Research and Development Institute, Gannoruwa, Peradeniya, Sri Lanka \\ ${ }^{2}$ Plant Pest Diagnostic Center, California Department of Food and Agriculture, Sacramento, California, USA
}

Accepted: $08^{\text {th }}$ May 2012

\begin{abstract}
An island-wide survey of mealybugs (Hemiptera: Pseudococcidae) conducted in 2008/09 helped identify two species of Rastrococcus from Sri Lanka. R. invadens Williams was identified from samples collected on Plumeria sp. and Ficus arnottiana, while $R$. rubellus Williams was found on Plumeria sp. Although $R$. invadens has been recorded in Sri Lanka before, this is the first record of the oriental mealybug, $R$. rubellus, from the country. $R$. rubellus was found in mixed colonies with $R$. invadens; so far, the infestations have not been associated with any severe crop losses. The survey revealed that $R$. rubellus is confined to a limited area in Colombo District. This restricted distribution suggested that it may be a new introduction to the country. Diagnostic characters to aid recognition of $R$. rubellus, and details of its distribution and host range within Sri Lanka are given.
\end{abstract}

\section{Key words: Mealybugs, Rastrococcus rubellus, Rastrococcus invadens, Sri Lanka}

\section{INTRODUCTION}

An epidemic of mealybugs (Hemiptera: Pseudococcidae) occurred in Sri Lanka in early 2008 , infesting a number of plant species and causing severe damage. A survey conducted in 2008/09 found that five species were responsible for the epidemic: Papaya mealybug, Paracoccus marginatus Williams and Granara de Willink on papaw and Plumeria spp. (Galanihe et al. 2010); Gray pineapple mealybug (Dysmicoccus neobrevipes Beardsley) on banana (Musa spp.) (Anon 2009); Cotton mealybug (Phenacoccus solenopsis Tinsley) on a wide range of crops and weeds (Prishanthini and Vinobaba 2009); Rastrococcus invadens Williams, on ficus \& Plumeria (Williams 2004); and R. rubellus Williams, on plumeria a new record for Sri Lanka. The two Rastrococcus species were found mostly feeding on mango trees (Mangifera indica) but were also found on Artocarpus integrifolius, Alocasia sp., Costus speciosus; and on Plumeria spp. This paper provides diagnostic characters to aid recognition of $R$. rubellus, and details of its distribution and host range within Sri Lanka as recorded in 2008/09.

\section{MATERIALS AND METHODS}

An island-wide mealybug survey was conducted from August 2008 to July 2009 to determine the pest mealybug species, their distribu-

*Corresponding author: laldam@yahoo.com tions and host plant ranges. Representative samples collected from Plumeria spp. and $\mathrm{Fi}$ cus arnottiana were preserved for authoritative identification by placing small infested pieces of plant in $70 \%$ ethanol. Each sealed, labeled vial was immersed in freshly boiled water for 20 minutes to denature enzymes and ensure optimal preservation. The samples were then shipped to the Plant Pest Diagnostic Center, California Department of Food and Agriculture, Sacramento, California, USA (CDFAPPDC) for authoritative identification.

At CDFA-PPDC, the mealybugs were prepared as archival-quality slide mounts by maceration of the body contents in $10 \% \mathrm{KOH}$, staining of the cuticle with acid Fuchsin and then slidemounting them in Canada balsam, using the method given by Watson \& Chandler (2000). They were then examined using a Zeiss compound microscope with phase contrast illumination at magnifications of $\times 25-x 800$. Specimens were identified using the keys in Williams (2004) and Williams and Granara de Willink (1992), and with reference to specimens in the California State Collection of Arthropods (CSCA) at CDFA-PPDC. One or more permanent slide mounts of each species were deposited in the insect museum of the Department of Agriculture, Sri Lanka, and some additional slides were deposited in CSCA.

One of the diagnostic characters noted in the field was colour of the body contents, but this 
was often obscured by the white coating of mealy wax on the insect's cuticle. The body content colour was most easily seen when a live mealybug was crushed and smeared on white paper.

This paper will cover only the observations made on Rastrococcus spp. The host ranges of R.invadens and $R$. rubellus were determined based on field observations. However, some of the host species recorded may not have been capable of sustaining a long-term infestation over multiple generations.

\section{RESULTS}

Pest species responsible for the mealybug epidemic

The main pest species was papaya mealybug, Paracoccus marginatus, which caused heavy damage, mainly to papaw and Plumeria spp. but more than 40 host species were recorded. It was observed to have spread all over the country (Galanihe et al. 2010). Of the four other pest species found, the gray pineapple mealybug (Dysmicoccus neobrevipes Beardsley), a polyphagous species (Ben-Dov 2012b), mainly damaged banana (Musa spp.) (Anon 2009). The cotton mealybug, Phenacoccus solenopsis Tinsley, infested a wide range of crops and weeds (Prishanthini and Vinobaba 2009; BenDov 2012c). $R$. invadens, which was collected from Sri Lanka for the first time by E.E. Green in 1900 (Williams 1986), and R. rubellus, a new record for Sri Lanka, were found together in mixed populations in which $R$. invadens was the dominant species. The number of $R$. rubellus specimens found was relatively low.

\section{Authoritative identification Rastrococcus species}

The two species of Rastrococcus in the mixed populations were identified by Gillian Watson as Rastrococcus invadens, the mango mealybug; and $R$. rubellus, a new country record from Sri Lanka.

\section{Diagnostic characters}

In the field, most Rastrococcus species differed from many other mealybugs because they did not form tight colonies and their ovisac wax was not sticky (Plate 1). The body of the adult female was oval, pale, flat, and completely covered with white powdery wax. A series of

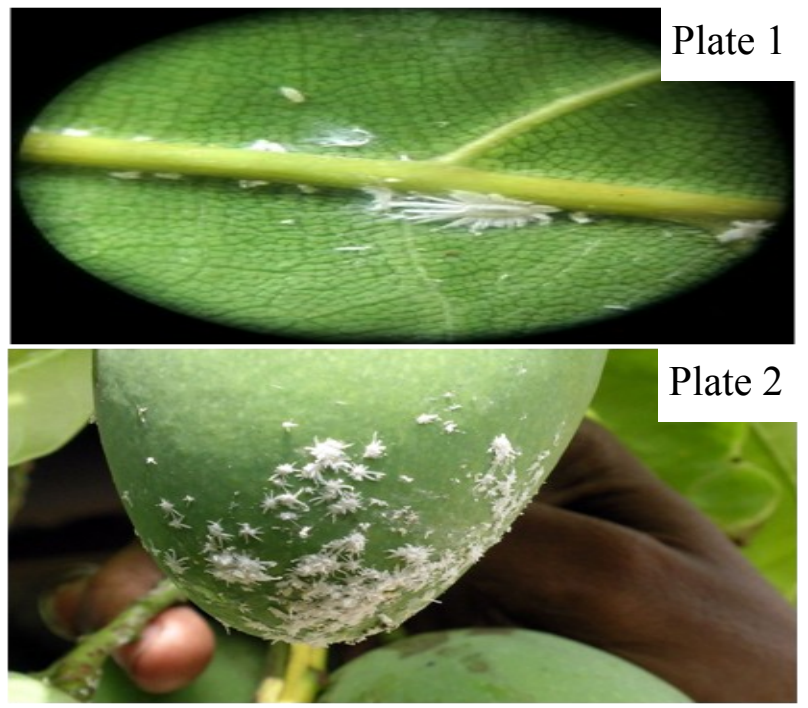

Plate 1 \& 2: Colours of Rastrococcus rubellus on mango leaves \& fruits

conspicuously long, white wax filaments was present around the body margin, giving the insect a star-like appearance. The marginal filaments were relatively short at the anterior end and become progressively longer towards the rear (Plate 2). The adult male had a translucent, pale yellow, elongated body, long manysegmented antennae and one pair of wings.

Rastrococcus invadens and $R$. rubellus are very similar to each other. In the field, adult females of $R$. rubellus were usually slightly larger than those of $R$. invadens. The colour of the body contents also differed, being pale green in $R$. invadens but pink in $R$. rubellus. In microscope slide mounts, the frontal cerarii of $R$. rubellus were almost always linked by sclerotized cuticle, whereas in $R$. invadens they were usually separated by a strip of membranous cuticle; this difference was illustrated by Williams (1989 and 2004).

\section{Host ranges}

In Sri Lanka, Rastrococcus spp. mainly infested mango, Mangifera indica L., but were also found on Artocarpus integrifolius L. f., Plumeria spp., Alocasia sp., Ficus sp. and Costus speciosus (J. König) Sm. R. invadens Williams was identified from samples collected on Plumeria sp. and Ficus arnottiana, and R. rubellus Williams was identified from Plumeria sp.

In West Africa, introduced $R$. invadens mainly infested mango and Citrus spp. (Williams 
1986). Mango, citrus, breadfruit, banana, Plumeria alba and Ficus spp. were reported by Agounké et al. (1988) as the most-attacked plants by $R$. invadens in West Africa; however, the species has a much wider host range that includes 65 plant species in 28 families (BenDov 2012d).

Information on $R$. rubellus in the literature is scarce. Its hosts have been recorded as M. indica, Plumeria rubra, Mallotus paniculatus, Ficus sp., Citrus aurantium, C. grandis and $C$. microcarpa (Ben-Dov 2012e; Agounké et al. 1988).

\section{Distributions}

Of the five pest mealybug species found in the 2008 epidemic, Paracoccus marginatus was the dominant species, being highly invasive. It probably originated from Mexico and/or Central America and has been spreading westwards around the globe. In Sri Lanka it quickly spread to numerous plant species all over the country (Galanihe et al. 2010). Dysmicoccus neobrevipes was found mainly in the Western province (Anon, 2009). Phenacoccus solenopsis was reported mainly from the Eastern province (Vinobaba and Prishanthini, 2009). R. invadens is native to Southern Asia, and is quite widespread in mainland southern Asia (Williams 2004). R. rubellus was described from Malaysia (Williams 1986) and has been reported also from Hong Kong, Indonesia and Laos (Ben-Dov et al. 2012e).

\section{DISCUSSION}

All 30 of the described species of Rastrococcus are native to the Oriental and Australasian regions, occurring in Australasia and southern Asia (Williams 1989). They feed on a range of fruit trees; none are host-specific, so they are all of potential economic importance wherever they may be accidentally introduced outside their native ranges. $R$. invadens caused major damage to mango, citrus and other fruits when accidentally introduced to Ghana and Togo, West Africa in 1981 (Williams 1989), with up to $80 \%$ loss of mango yield in Ghana (Willink and Moore 1988). It spread very rapidly throughout West Africa (Williams 1986). Infestation of mango fruits by $R$. invadens was found to affect their nutritional status (Tobih et al. 2002).

Five species of Rastrococcus have been recorded from Sri Lanka in the literature: $R$. iceryoides (Green), $R$. invadens, $R$. mangiferae (Green), R. spinosus (Robinson) and $R$. taprobanicus Williams. Green (1922) recorded $R$. spinosus from Sri Lanka; however, Williams (2004) studied Green's slide material and found that Green had misidentified a mixture of $R$. invadens and $R$. taprobanicus as $R$. spinosus. So there is no evidence that $R$. spinosus has ever been established in Sri Lanka, and only four Rastrococcus species have been recorded from Sri Lanka before.

The new record of $R$. rubellus brings the total number of Rastrococcus species present in Sri Lanka to five (Table 1). To date, $R$. rubellus has not been observed causing any significant economic damage to mango or other fruit trees on the island.

In view of E.E. Green's collection of $R$. invadens from Sri Lanka in 1900 (Williams

Table 1: Rastrococcus species recorded in Sri Lanka

\begin{tabular}{|c|c|c|c|c|}
\hline \multirow{3}{*}{$\begin{array}{l}\text { Rastrococcus species } \\
R \text {. iceryoides }\end{array}$} & Location & Host-plant(s) & Year collected & Reference \\
\hline & Not specified & $\begin{array}{l}\text { Tephrosia candida; Odina } \\
\text { woodier; Callicarpa lanata; Wendlandia } \\
\text { notoniana }\end{array}$ & pre-1923 & Green (1922) \\
\hline & $\begin{array}{l}\text { Peradeniya; Kandy; } \\
\text { Murunkan }\end{array}$ & $\begin{array}{l}\text { Malvaceae; Honckenya ficifolia; Lannea } \\
\text { wodier; Murrayakoenigii; Capparis sp. }\end{array}$ & $\begin{array}{l}1909 \\
1912\end{array}$ & Williams (1989) \\
\hline R. invadens & $\begin{array}{l}\text { Peradeniya } \\
\text { Colombo } \\
\text { Moratuwa }\end{array}$ & $\begin{array}{l}\text { Ficus } \mathrm{sp} . \\
\text { Ficus arnottiana } \\
\text { Plumeria } \mathrm{sp} .\end{array}$ & $\begin{array}{l}1900 \\
\text { 11.vi.200929.x.200 } \\
9\end{array}$ & $\begin{array}{l}\text { Williams (1989) } \\
\text { Current paper }\end{array}$ \\
\hline R. mangiferae & $\begin{array}{l}\text { Punduloya } \\
\text { Maskelia } \\
\text { Bandarawella }\end{array}$ & $\begin{array}{l}\text { Mangifera indica } \\
\text { Mangifera indica }\end{array}$ & $\begin{array}{l}\text { pre-1897 } \\
1922\end{array}$ & $\begin{array}{l}\text { Green }(1896) \\
\text { Williams (1989) }\end{array}$ \\
\hline R. taprobanicus & $\begin{array}{l}\text { Trincomalee } \\
\text { Ibbagamuwa } \\
\text { Colombo }\end{array}$ & $\begin{array}{l}\text { undet. host } \\
\text { undet. hosts }\end{array}$ & $\begin{array}{l}\text { No date; } \\
\text { identified by Green } \\
19641979\end{array}$ & $\begin{array}{l}\text { Williams (1989) } \\
\text { Williams (2004) }\end{array}$ \\
\hline R. rubellus & Moratuwa & Plumeria sp. & 11.vi.2009 & Current paper \\
\hline
\end{tabular}


1986), this species might be native to the island, or it may have been introduced a long time ago; if the latter, it might have died out in Sri Lanka but then have been reintroduced recently. $R$. invadens and $R$. rubellus were collected only in a limited area in Sri Lanka, in the Colombo District of the Western province of Sri Lanka, suggesting that one or both species may have been introduced recently from mainland Asia.

\section{ACKNOWLEDGEMENTS}

The authors wish to thank the Director, Horticulture Research and Development Institute, Gannoruwa, Sri Lanka, and the Director, California Department of Food and Agriculture, Sacramento, California, USA for the facilities provided for this investigation.

\section{REFERENCES}

Agounké D, Agricola U and Bokonon-Ganta HA 1988 Rastrococcus invadens Williams (Hemip tera: Pseudococcidae), a serious exotic pest of fruit trees and other plants in West Africa. Bull. Ent. Res. 78: 695-702.

Anon 2009 Banana mealybug, identification and control (in Sinhala). Leaflet. Plant Protection Service, Department of Agriculture, Peradeniya, Sri Lanka.

Ben-Dov Y 1994 A systematic catalogue of the mealybugs of the world (Insecta: Homoptera: Coccoidea: Pseudococcidae and Putoidae) with data on geographical distribution, host plants, biology and economic importance. Intercept Limited, Andover, UK. 686 pp.

Ben-Dov Y 2012a ScaleNet, Paracoccus marginatus. http://www.sel.barc. usda.gov/catalogs/ pseudoco/Paracoccusmarginatus.htm (Accessed on 6 March 2012)

Ben-Dov Y 2012b ScaleNet, Dysmicoccus neobrevipes. http://www.sel. barc.usda.gov/catalogs/ps eudoco/Dysmicoccusneobrevipes.htm (Accessed on 6 March 2012)

Ben-Dov Y 2012c ScaleNet, Phenacoccus solenopsis. http://www.sel. barc.usda.gov/catalogs/pse udoco/ Phenacoccussolenopsis.htm(Accessed on 6 March 2012)

Ben-Dov Y 2012d ScaleNet, Rastrococcus invadens. http://www. sel.barc.usda.gov/catalogs/ pseudoco/ Rastrococcusinvadens.htm(Accessed on 6 March 2012)

Ben-Dov Y 2012e ScaleNet, Rastrococcus rubellus. http://www.sel.barc .usda.gov/catalogs/ pseudoco/Rastrococcusrubellus.htm (Accessed on 6 March 2012)
Ben-Dov Y, Miller DR and Gibson GAP 2012 ScaleNet. A data base of the scale insects of the wor ld. http://www.sel.barc.usda.gov/scalenet /query. htm (Accessed on 6 March 2012)

Galanihe LD, Jayasundera MUP, Vithana A, Asselaarachchi N and Watson GW 2010 Occurrence, distribution and control of papaya mealybug, Paracoccus marginatus (Hemiptera: Pseudococcidae), an invasive alien pest in Sri Lanka. Tropical Agricultural Research \& Extension. 13 (3): 81-96.

Green EE 1896 Catalogue of Coccidae collected in Ceylon. Indian Mus. Notes. 4: 2-10.

Green EE 1922 The Coccidae of Ceylon, Part V. Dulau \& Co., London. Pp. 345-472

Tobih FO, Omolove AA, Ivbijaro MF and Enobakhare DA 2002 Effects of field infestation by Rastrococcus invadens Williams (Hemiptera: Pseudococcidae) on the morphology and nutritional status of mango fruits, Mangifera indica L. Nigeria Crop Protection. 21(9): 757-761.

Varshney RK 1992 A check list of the scale insects and mealy bugs of South Asia. Part-1. Records of the Zoological Survey of India, Occasional Paper (No. 139): 1-152.

Vinobaba M Laxmi and Prishanthini M 2009 A new invasive species of mealybug from the East. Department of Zoology, Eastern University, Vantharumoolai, Chenkalady, Sri Lanka. 5p.

Watson GW and Chandler LR 2000 Identification of mealybugs important in the Caribbean region. Second edition (revised). 40 pp. CABI Bioscience, Egham, UK

Williams DJ 1986 Rastrococcus invadens sp. n. (Hemiptera: Pseudo -coccidae) introduced from the Oriental Region to West Africa and causing damage to mango, citrus and other trees. Bull. Ent. Res. 76: 695-699.

Williams DJ 1989 The mealybug genus Rastrococcus Ferris (Hemiptera: Pseudococcidae). Syst. Ent. 14(4): 433-486.

Williams DJ 2004 Mealybugs of Southern Asia. The Natural History Museum, London. Kuala Lumpur: Southdene SDN. BHD. 896 pp.

Williams DJ and Granara de Willink MC 1992 Mealybugs of Central and South America. CAB International, Wallingford, U.K. 635p.

Willink E and Moore D 1988 Aspects of the biology of Rastrococcus invadens Williams (Hemiptera: Pseudococcidae), a pest of fruit crops in West Africa, and one of its primary parasitoids, Gyranusoidea tebygi Noyes (Hymenoptera: Encyrtidae). Bull. Ent. Res. 78: 709-15. 